\title{
Treibt Glutamat die Zellvermehrung beim Prostatakarzinom an?
}

Glutamat im Serum entpuppt sich als potenzieller Biomarker für die Aggressivität von Prostatakarzinomen. In einer Studie waren die Glutamatspiegel bei einem Gleason-Score $\geq 8$ signifikant höher im Vergleich zu Werten unter 7.

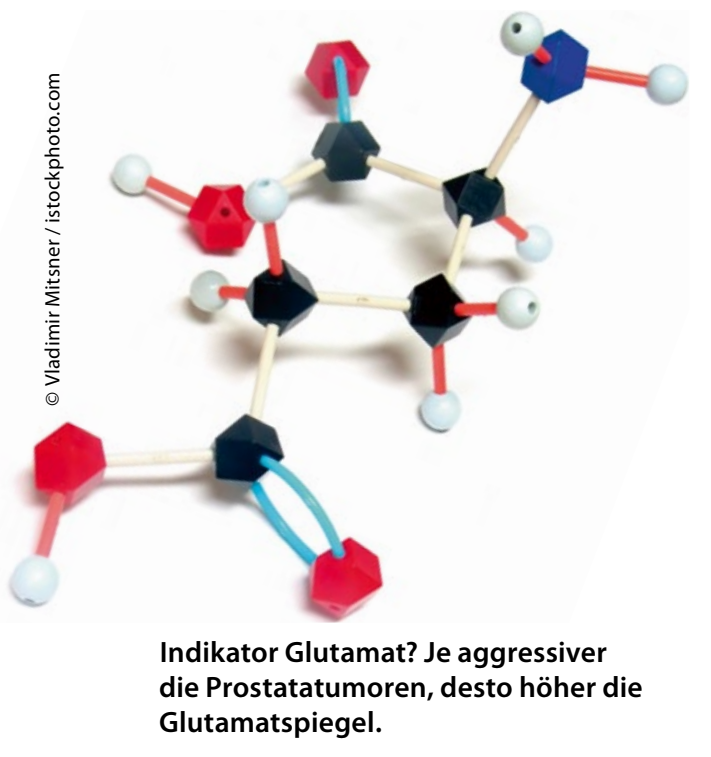

Dereits vor drei Jahren wurde festgestellt, dass bei den meisten Männern mit Prostatakarzinom (PCa) die Glutamatspiegel im Tumorgewebe signifikant höher sind als im Prostatagewebe von Männern mit benigner Prostatahyperplasie. Außerdem hat sich gezeigt, dass bestimmte Rezeptoren für Glutamat bei der Tumorentstehung, etwa von Gliomen und Neuroblastomen, beteiligt sind. Gliomzellen mit hohen Glutamatkonzentrationen haben auch eine hohe Proliferationsrate. Glutamatantagonisten bremsen zudem in der Zellkultur die Tumorzellvermehrung, etwa von Kolonadenokarzinomen, Melanomen, Lungenund Mammakarzinomen.

Um die klinische Relevanz der Glutamatserumwerte zu bestimmen, untersuchten US-amerikanische Urologen die Serumwerte bei 60 Männern ohne Krebs, bei 197 Männern mit primärem PCa und bei 109 Männern mit metastasiertem PCa. Zudem bestimmten sie Glutamatrezeptoren im Gewebe sowie den Effekt der Rezeptorblockade auf PCa-Zellen.

Im Vergleich zu gesunden Männern waren die Serumglutamatwerte bei wei- ßen und afroamerikanischen Männern mit primärem Karzinom signifikant erhöht ( $\mathrm{p}=0,003)$, bei Männern mit metastasiertem Karzinom dagegen nur bei Afroamerikanern. Bei Männern mit primärem Prostatakarzinom waren die Glutamatspiegel um so höher, je aggressiver die Tumoren waren.

Während sich der Glutamatrezeptor GRM1 in Zellen aus gesundem Prostatagewebe nicht oder nur schwach nachweisen ließ, war der Rezeptor in Krebszellen primärer PCa und in Metastasen stark erhöht. Schließlich ließ sich mit dem GRM1-Antagonisten Riluzol - einem Medikament zur Therapie bei amyotropher Lateralsklerose - in vitro die Vermehrung von Prostatazellen hemmen. Die Wirkung beruht zum Teil darauf, dass die Freisetzung von Glutamat unterbunden wird. Werden Prostatazellen in Kulturmedien ohne Glutamat gehalten, können sie sich kaum vermehren. Glutamatrezeptorblocker bewirkten in In-vitro-Versuchen darüber hinaus, dass PCa-Zellen nicht mehr wandern konnten und ihre Invasionsfähigkeit einbüßten. Offenbar sind PCa-Zellen auf die Signalweiterleitung über den GRM1-Rezeptor angewiesen.

Fazit: Die Forscher gehen davon aus, dass hohe Glutamatspiegel im Serum Vermehrungsraten und Aggressivität von Zellen primärer Prostatakarzinome bei Weißen und Afroamerikanern sowie von Zellen metastasierter Prostatakarzinome nur bei afroamerikanischen Patienten erhöhen. Jetzt seien größere Studien erforderlich, um den Grund für die Unterschiede bei den Ethnien herauszufinden.

Peter Leiner

Koochekpour S et al. Serum Glutamate Levels Correlate with Gleason Score and Glutamate Blockade Decreases Proliferation, Migration, and Invasion and Induces Apoptosis in Prostate Cancer Cells. Clin Cancer Res. 2012;18(21):5888-901. 